\title{
Design and Research on English Listening Teaching Assisted by Computer Multimedia
}

\author{
https://doi.org/10.3991/ijet.v12i01.6053 \\ Danlie Ni \\ Chongqing University of Technology, Chongqing, China \\ danlie ni@yahoo.com
}

\begin{abstract}
- this paper mainly introduces the theoretical basis, principle and design theory of listening teaching of foreign language assisted with computer multimedia, analyzes the demand of English listening teaching assisted by computer multimedia in one school, collects and analyzes questionnaire carefully and understand the situation of English listening teaching in this school. Explore the practice of English listening teaching assisted by computer multimedia in one school, relating to material selection and teaching strategy of English listening teaching, at the same time; analyze the practice results of English listening teaching assisted by computer multimedia in this school. Sort out and analyze the collected data, attain the results of this exploration and propose suggestions for problems existed in English listening teaching assisted by computer multimedia.
\end{abstract}

Keywords—English listening teaching; computer multimedia; teaching method.

\section{Introduction}

Applying multimedia into foreign language teaching to change the teaching method of foreign language and improve the quality of foreign language teaching has become one of important aspects of our foreign language teaching method and is also the trend of upgrading and development of foreign language teaching method in the present world[1]. The CAI teaching with adoption of multimedia can provide various teaching information, increase the expression forms of teaching content, play and use the coordination function of various senses among students fully and make language practice activities effectively. The CAI teaching with adoption of multimedia can not only realize communication between people and computer, but also realize the communication between students and communication between teachers and students. At the same time, it can make various kinds of listening teaching courseware with adoption of multimedia, combining picture, text, voice and image together, which enable students to attain all-around experience, optimize education structure and improve teaching quality. The scientific research shows that learning can reach the best effect with comprehensive 
stimulation where vision accounts for $83 \%$, listening accounts for $11 \%$, feeling accounts for $3 \%$, tasting accounts for $2 \%$ and smelling accounts for $1 \%$. With combination of listening and seeing, the memorizing of courses after two hours can reach $85 \%$ and the memory can remain $65 \%$ after 72 hours. In the listening teaching with adoption of computer multimedia, the students are not studying with teachers step by step passively and the students can control own study progress based on their different degrees and requirements, get out of the passive situation and become active learning individual with the help of computer, which will never become tired and never lose its temper no matter how many times you question.

On the other hand, adopting multimedia to assist college English listening teaching release the labor intensity and improve the working enthusiasm of teachers to some extent. Problems of lacking of professional teachers and less class hours etc are widespread in English listening teaching and the multimedia network system provides a lot of teaching resource to teachers, who can prepare lessons on computer, revise teaching material according to different requirements and share class material with students; make use of examination system to make paperless examination, at the same time, the teacher can make examination analysis on computer too; the network system provides vivid and lively listening material to teachers and students and build up a creative platform for teaching. The teachers can not only prepare listening material by themselves but also teaching based on the material provided by internet. Teaching in multimedia language laboratory enables easy operation for teachers and the teachers can understand the learning progress and process of students easily. The teacher can group the students based on their levels, provide different language sources to students of different degrees with multi-channel playback device and relieve the teacher of listening class from tedious and repetitive mechanical teaching[2].

\section{Principle of Listening Teaching of Foreign Language Assisted by Computer Multimedia}

As a new and special teaching method of foreign language teaching, the foreign language teaching assisted by multimedia should comply with the rule of language teaching and obey the general principle of foreign language teaching. These principles include principle of communication, principle of cognition, principle of culture and principle of emotion etc. These principles are common principles of foreign language teaching and suitable for foreign language teaching of any purpose and any forms.

Applying multimedia computer technology into foreign language teaching only plays a supporting role, but it should also form into own system, which is not only the requirement of language as symbol system but also the demand of cognitive development of learners. Therefore, the design of foreign language teaching assisted by multimedia not only needs to obey the above basic principles of foreign language teaching but also needs to combine the characteristics of multimedia computer as well as the demand for developing foreign language teaching and confirm the following principles: principle of learner center, principle of optimization, principle of simple, principle of effectiveness, principle of interactivity and principle of cooperation etc. 


\subsection{Principle of Communication}

The principle of communication presents the modern foreign language teaching idea which takes improving the language using ability and communication ability for students as objectives. Foreign language communication ability refers to the ability of learners who make use of the learned language knowledge to make language understanding (listening and reading) and language expression (speaking and writing). Based on this point, the computer multimedia courseware not only needs to meet the learning of language knowledge (grammar and vocabulary etc), but also provide conditions for practice of foreign language communication. Therefore, a better method is to combine the two together, that is place grammar, vocabulary and other language knowledge into simulated or real communication scenes, express language material with illustrations, voice and images, make full use of the interactive characteristics of multimedia, help learners to use while studying, learn language knowledge subconsciously and improve communication ability[3].

\subsection{Principle of Cognition}

Principle of cognition is a principle that any teaching needs to obey. In the foreign language teaching, it stresses that the principle of cognition includes two aspects: one aspect is to fully consider about the influence of learners' original language knowledge and cognition of the world on foreign language learning, who compare the similarities and differences of structural characteristics between mother language and foreign language and deepen learners' understanding of new language system knowledge; the second aspect is to fully consider about the function of study strategy and memory habit of students[4]. So in the instructional design process, firstly the teachers need to evaluate the cognitive characteristics of courseware users-the learners, clarify their existing language level and understand their study strategy and memory habit to improve the teaching efficiency at maximum. On the other hand, the designed courseware should also help the learners to go beyond self-restraint, contact different study methods, get rid of bad study habits, cultivate efficient study habit, which are very helpful in improving the comprehensive quality of students.

\subsection{Principle of Culture}

The proposing of principle of culture is not only the demand of foreign language itself, but also the necessity of foreign language teaching serving for society and adapting social development. On one hand, the close relationship between language and culture determines that the language teaching can't be separated from the teaching of related culture; on the other hand, as cross-cultural communication has become the characteristic of times, cross-cultural awareness and cross-cultural communication ability have become important components of foreign language teaching. The design of foreign language teaching assisted by computer multimedia can make full use of the diversity and integration advantage of its information carrier, present language material and its cultural background at the same time, select different sides of various different cultures and the same culture, compare them with original culture of students and strengthen the sensitivity of students for cultural difference. In the foreign language listening teaching, it also needs to consider about the input of cultural background knowledge before listening, so the students can get familiar with listening material in listening process and understand deeper listening content beyond language level. 


\section{Demand Analysis of English Listening Teaching Assisted by Computer Multimedia}

In this questionnaire, the questionnaire was sent to students with different levels from grade one to grade four of Foreign Language Department of one school at random as well as few students of other schools. There are totally 320 questionnaires and 318 valid questionnaires have been received. To ensure the authenticity and reliability of this questionnaire, each student was told that there is no absolutely correct answer for each question before sending out the questionnaire and the questionnaire was made anonymously. The answer for each question has five grades (I. totally agree, 2 agree, 3 not sure, 4 disagree, 5 totally disagree)

Table 1. Students' understanding of the computer multimedia assisted foreign language teaching

\begin{tabular}{|c|c|c|c|c|c|}
\hline $\begin{array}{c}\text { I am very understanding of computer } \\
\text { multimedia assisted foreign language } \\
\text { teaching }\end{array}$ & $\begin{array}{c}\text { Couldn't agree } \\
\text { more }\end{array}$ & Agree & determine & $\begin{array}{c}\text { Don't agree } \\
\text { with }\end{array}$ & $\begin{array}{c}\text { Strongly } \\
\text { disagree }\end{array}$ \\
\hline Answer number & 0 & 15 & 95 & 172 & 25 \\
\hline The percentage & $0.0 \%$ & $5.7 \%$ & $26.3 \%$ & $52.1 \%$ & $5.2 \%$ \\
\hline
\end{tabular}

Table 2. Students' perceptions of computer multimedia assisted foreign language teaching

\begin{tabular}{|c|c|c|c|c|c|}
\hline $\begin{array}{c}\text { Multimedia teaching of } \\
\text { English listening learning } \\
\text { help }\end{array}$ & $\begin{array}{c}\text { Couldn't agree } \\
\text { more }\end{array}$ & Agree & determine & Don't agree with & $\begin{array}{c}\text { Strongly disa- } \\
\text { gree }\end{array}$ \\
\hline Answer number & 74 & 152 & 36 & 9 & 5 \\
\hline The percentage & $24.5 \%$ & $61.3 \%$ & $10.2 \%$ & $2.3 \%$ & $1.9 \%$ \\
\hline
\end{tabular}

Table 3. Student's attitude to the traditional listening teaching method

\begin{tabular}{|c|c|c|c|c|c|}
\hline $\begin{array}{c}\text { The abolition of the tradition- } \\
\text { al listening teaching }\end{array}$ & $\begin{array}{c}\text { Couldn't agree } \\
\text { more }\end{array}$ & Agree & determine & $\begin{array}{c}\text { Don't agree } \\
\text { with }\end{array}$ & $\begin{array}{c}\text { Strongly disa- } \\
\text { gree }\end{array}$ \\
\hline Answer number & 36 & 39 & 36 & 125 & 65 \\
\hline The percentage & $10.5 \%$ & $6.5 \%$ & $10.2 \%$ & $36.1 \%$ & $30.5 \%$ \\
\hline
\end{tabular}

Table 4. The importance of listening in language learning

\begin{tabular}{|c|c|c|c|c|c|}
\hline $\begin{array}{c}\text { Listening skills in English language } \\
\text { learning is very important }\end{array}$ & $\begin{array}{c}\text { Couldn't agree } \\
\text { more }\end{array}$ & Agree & determine & $\begin{array}{c}\text { Don't agree } \\
\text { with }\end{array}$ & $\begin{array}{c}\text { Strongly } \\
\text { disagree }\end{array}$ \\
\hline Answer number & 135 & 139 & 25 & 18 & 6 \\
\hline The percentage & $42.1 \%$ & $43.6 \%$ & $10.2 \%$ & $6.1 \%$ & $3.5 \%$ \\
\hline
\end{tabular}

\subsection{Questionnaire Statistics}

From table 1 we can find out that most of students are not familiar with foreign language teaching assisted by computer media, especially for listening teaching, which is normal. The education technology has formed in $19^{\text {th }}$ century, but in China, the education technology only started till 1920s to 1930 s and the promotion process is quite slow. 
On the other hand, in the listening class, most of teachers teach with combination of textbooks and recording material, even in the multimedia language lab, the computers are only used as device for playing the recording. Moreover, the students are accustomed to the teaching mode of listening recording material with headsets and checking the answer with teachers.

It is easy to find out from table 2 that students are not very familiar with foreign language teaching assisted by computer multimedia, but they expressed that they like this kind of teaching method. Just as mentioned in former chapters, foreign language teaching assisted by multimedia can relieve the anxiety of students in class and stimulate learning interest etc, we will not explain again.

\subsection{Questionnaire Analysis}

From table 3 we can find out that most of students think that the traditional listening teaching method can't be abolished, but we can find out the conclusion of table 2 that most of students like foreign language teaching assisted by computer multimedia. Are they contradictory to each other? But after careful consideration, it is easy for us to find out the following conclusions:

(1) Under current situation, the popularity of multimedia technology as well as the multimedia technology of teachers is still a big issue. As far as the write knows, most of schools are using multimedia more and more, but due to the limitation of teachers' technology level, most of teachers use the multimedia just for use and the result is that the advantage of multimedia technology has not been well used and some are even too much of a good thing. During the interviews with students, the writer learned that most of teachers just use the computer as recorder in listening class and the teacher only transfer playing the tape with recorder to computer. The students are sitting in the multimedia language lab with headsets, but there is no big change in listening process and mode. The teachers are still playing the tape, pausing and then examining the answer and they seldom process the recording material or supplement with other image and video materials etc.

(2) The traditional listening teaching mode has limitations, but the communication between students and teachers, this kind of emotional interaction can't be replaced by any machine. After all, computer multimedia is a machine and it can't replace teachers completely to make evaluation and feedback of students. Therefore, the most wise and effective method is to combine traditional listening teaching and foreign language listening teaching assisted by multimedia, which not only make use of the human resources of teachers but also fully play the positive effect of multimedia to reach the aim of improving listening level of students.

From table 4, 5, 6, we can find out some enlightenment. There is not doubt that most of students have realized the importance of listening in language study, which is closely connected with the increasing focus of foreign language learning on communication ability[8]. To follow this trend, both educators and foreign language learners are changing their concept and more and more realize the importance of listening and speaking in foreign language study but not the former deaf or dumb type of foreign language learning. In addition, the nature of language learning also determines the primacy and importance of listening and speaking. Just as English educator L. Alexander said, "if there is no listening, there is no speaking, there is no speaking and then there is no listening, there is no reading and then there is no writing." 
Table 5. Listening to language learning

\begin{tabular}{|c|c|c|c|c|c|}
\hline $\begin{array}{c}\text { Listening skills in English lan- } \\
\text { guage learning is important }\end{array}$ & Couldn't agree more & Agree & determine & $\begin{array}{c}\text { Don't agree } \\
\text { with }\end{array}$ & $\begin{array}{c}\text { Strongly } \\
\text { disagree }\end{array}$ \\
\hline Answer number & 75 & 98 & 59 & 55 & 21 \\
\hline The percentage & $23.8 \%$ & $25.6 \%$ & $20.5 \%$ & $18.2 \%$ & $9.5 \%$ \\
\hline
\end{tabular}

Table 6. On the degree of focus on listening comprehension in foreign language learning

\begin{tabular}{|c|c|c|c|c|c|}
\hline $\begin{array}{c}\text { I'm very pay attention to the } \\
\text { listening learning }\end{array}$ & $\begin{array}{c}\text { Couldn't agree } \\
\text { more }\end{array}$ & Agree & determine & $\begin{array}{c}\text { Don't agree } \\
\text { with }\end{array}$ & $\begin{array}{c}\text { Strongly } \\
\text { disagree }\end{array}$ \\
\hline Answer number & 62 & 98 & 65 & 44 & 41 \\
\hline The percentage & $20.8 \%$ & $31.6 \%$ & $22.5 \%$ & $12.2 \%$ & $14.2 \%$ \\
\hline
\end{tabular}

Table 7. Hearing the proportion in all kinds of qualification examination

\begin{tabular}{|c|c|}
\hline Test type & The proportion of listening \\
\hline CET4 & $1 / 5$ \\
\hline CET6 & $1 / 5$ \\
\hline TEM4 & $1 / 5$ \\
\hline TEM8 & $1 / 5$ \\
\hline TOFEL & $1 / 3$ \\
\hline
\end{tabular}

It is well known that the examination system determines the direction of education to a great extent. With the globalization development of economy and culture, more and more people realize the communication function of language learning, while listening is the top skill for interpersonal communication. As both teachers and students realize the importance of listening level, and then they must put emphasis on the training of listening skill. However, have they received satisfactory result? We can find answers from the following table 8.

Table 8. The cause of the students' listening level is not high

\begin{tabular}{|c|c|c|c|c|c|}
\hline & $\begin{array}{c}\text { Couldn't agree } \\
\text { more }\end{array}$ & Agree & determine & Don't agree with & $\begin{array}{c}\text { Strongly } \\
\text { disagree }\end{array}$ \\
\hline Less training time & 32 & 84 & 56 & 71 & 62 \\
\hline percentage & $9.8 \%$ & $26.3 \%$ & $12.3 \%$ & $24.1 \%$ & $21.3 \%$ \\
\hline Improper teaching methods & 56 & 85 & 77 & 66 & 32 \\
\hline percentage & $9.8 \%$ & $23.6 \%$ & $24.1 \%$ & $21.2 \%$ & $3.6 \%$ \\
\hline $\begin{array}{c}\text { Behind the listening materi- } \\
\text { al }\end{array}$ & 79 & 84 & 66 & 75 & 31 \\
\hline percentage & $24.3 \%$ & $26.3 \%$ & $19.6 \%$ & $17.2 \%$ & $11.2 \%$ \\
\hline The real environment & 74 & 84 & 69 & 55 & 32 \\
\hline percentage & $24.5 \%$ & $36.2 \%$ & $23.6 \%$ & $17.5 \%$ & $9.6 \%$ \\
\hline
\end{tabular}

Among over three hundred students who have made questionnaires investigation, there are only $6.3 \%$ of students satisfied with their listening level, and then what has caused the worrying result? Let us check table 9. 
Table 9. Comparison of two traditional listening comprehension test

\begin{tabular}{|c|c|c|c|}
\hline & Before the test & After the test & Increase the percent- \\
\hline & average & average & age \\
\hline The experimental group & 61.2 & 66.5 & 6.9 \\
\hline The control group & 62.3 & 64.1 & 3.2 \\
\hline
\end{tabular}

From table 9 we can find out that most of students believe that the old-fashioned listening material as well as not real language environment is the main reason for low listening level. According to the rough statistics of writer, at present, most of the content of listening material is, more in written form, which is suitable for implementing reading activity but not listening activity. Obviously, for learners who can read and understand foreign language material, they may not understand if broadcasted in the form of listening and this is the difference between listening and reading. Moreover, the characteristics of repetition, pause, tone use and omission etc in real language can be presented in the written material. For example, in the $3^{\text {rd }}$ and 4 th "Step-By-Step English Listening 2000", nearly all the teachers and students who have used this book before reflected that it is quite difficult; for some listening content, it needs to ponder several time to understand even read the text material and it will be more difficult for students to understand. From another viewpoint, it also puts forward higher requirement for teachers, which is they can't hold the book recording material mechanically as a broadcaster but should spend time in designing listening material carefully, for which part the writer will make detailed introduction in the following part.

Table 10. Listening comprehension tests twice every content of contrast

\begin{tabular}{|c|c|c|c|c|}
\hline & Content & score & Before the test & After the test \\
\hline \multirow{6}{*}{ The experimental group } & Statement dictation & 20 & 11.2 & 12.6 \\
\hline & Statement comprehension & 20 & 13.3 & 14.2 \\
\hline & Conversation comprehension & 20 & 12.3 & 13.3 \\
\hline & Passage comprehension & 20 & 11.5 & 12.3 \\
\hline & Spot dictation & 20 & 14.6 & 14.8 \\
\hline & Total score & 100 & 63.5 & 66.3 \\
\hline \multirow{6}{*}{ The control group } & Statement dictation & 20 & 11.2 & 11.5 \\
\hline & Statement comprehension & 20 & 13.6 & 14.2 \\
\hline & Conversation comprehension & 20 & 12.8 & 12.9 \\
\hline & Passage comprehension & 20 & 11.2 & 11.6 \\
\hline & Spot dictation & 20 & 14.8 & 14.2 \\
\hline & Total score & 100 & 62.3 & 64.2 \\
\hline
\end{tabular}

\subsection{Conclusion of Questionnaire}

Various proofs prove that the adoption of vision is very crucial in teaching process. To attain more comprehensive answer, the writer has interviewed ten teachers and ten students. The questions are very open: do you think vision is helpful in listening understanding? How many advantages does vision has for listening understanding? The following is the summary of answers from teachers and students: 
1. Vision is helpful for listening understanding under most situations.

2. In traditional listening class, students attain information from textbook and tape merely and this kind of mode makes them feel boring. Therefore, the presentation of video material can stimulate the interest of students as well as learning demand, which makes the study interesting and active.

3. Under some situations, video information will distract the attention of students, especially for students with weak self-control ability; this kind of video material is not good for study.

\section{$4 \quad$ Practical Exploration of English Listening Teaching Assisted by Computer Multimedia}

\subsection{Strategy of Instructional Design from the Perspective of Teacher}

Operational Strategy In teaching practice, the teacher should make practical teaching plan based on progressive learning principle and with combination of characteristics of students and learning content. Swiss psychologist Piaget believes that all knowledge development process is the product of assimilating and adapting these two opposite and unified processes. Assimilation refers to that based on own way of thinking, people adopt the learned knowledge to explain and construct external things, that is to merge new information into original knowledge system. Adaption means people realize the structural characteristics of external things and revise original knowledge to include new information. Therefore, to make students adapt to new knowledge quickly, the teacher should adopt operational strategy to make the teaching program meets the cognition development rules and progressive principle.

Table 11.

Two family album USA video clips test contrast

\begin{tabular}{|c|c|c|c|c|}
\hline & Number of people & Before the test & After the test & Average \\
\hline The experimental group & 35 & 65.2 & 74.1 & 72.6 \\
\hline The control group & 33 & 70.2 & 77.1 & 69.6 \\
\hline
\end{tabular}

Evaluation Strategy Evaluation strategy carries through principles of timeliness, objectivity, integrity and guidance and is with incentive function (that is making people think deeply and inspiring people to endeavor; playing promotion and supervision function), diagnosis function (that is diagnosing current teaching situation and discovering the root cause of problem) and regulatory function (that is adjusting teaching method based on feedbacks). When adopting this strategy, the teacher should pay attention that evaluation is a method but not the teaching purpose. The teaching should focus on mastery of knowledge and transferring knowledge into skill for students.

Strengthening Remedial Strategy Strengthening remedial strategy can be combined with evaluation strategy and applied flexibly. The teacher can adopt purposeful remedial strategy on the basis of making diagnostic evaluation for students to make sure that the teaching target can be accomplished smoothly. This strategy fully presents strategy selection principle of teaching students in accordance with their aptitude and 
step by step, which enables students of different levels to attain the happiness of success and then motivate their enthusiasm in study and strengthen the learned knowledge.

\subsection{Strategy of Instructional Design from the Perspective of Student}

Strategy of Interest Simulation The teacher should start fro the interest of students and make students study actively based on own needs. For example, when teachers teach theories, they can specify the abstract concepts with multimedia to cultivate the study interest of students. When exploring the teaching schools, the teachers can let the students watch video/CD about silence method, listening and speaking method, communication method, suggestion method and other teaching methods, which make them form perceptual knowledge of each teaching school and then make up the shortage of boring teaching. When making discourse analysis, the teachers can select movie clip based on language function, make students experience the code-switching principle under different occasions as well as conversational principle among different genders, different ages and different statuses, enable students to write related comments with combination of linguistic theory and cultivate their interest to difficult linguistics and understanding of literary theory terms in a further way.

Strategy of Emotional Input Emotion plays a catalytic role in thinking and the valuable experience can fully play the potentiality. Based on this, it needs emotion input in teaching and makes students willing to learn, like learning and happy to learn. During adoption of this strategy, the teacher should fully consider about the gender difference, character difference, anxiety degree and other non-intelligence factors and assign different learning tasks based on specific teaching content, such as let the extroverted students to make courseware demonstration, role play, oral report and other activities on platform; let the introverted students to make deep thinking, theoretical analysis, logical reasoning, instant writing and other activities. In this way, it can meet the demand of psychological and emotional difference, motivate the enthusiasm of all students in a practical way and make people involve in study wholeheartedly to improve study efficiency.

Collaboration Study In collaboration study, the students participate equally, inspire each other and improve together. For example, when teaching the characteristics of language, the students can make use of online information, CD, video, audio-visual materials etc to collect different discussions for language characteristics, explore the essential difference between human language and animal language, and discuss the shifting, generative and cultural transmission characteristics which animal language lacks specifically and then strengthen the understanding of language nature. This activity has advantages of clear target, division and coordination, complementary and highefficient.

\section{$5 \quad$ Cast Analysis}

Adopting multimedia to assist college English listening teaching release the labor intensity and improve the working enthusiasm of teachers to some extent. Problems of lacking of professional teachers and less class hours etc are widespread in English listening teaching and the multimedia network system provides a lot of teaching resource to teachers, who can prepare lessons on computer, revise teaching material according to different requirements and share class material with students; make use of 
examination system to make paperless examination, at the same time, the teacher can make examination analysis on computer too; the network system provides vivid and lively listening material to teachers and students and build up a creative platform for teaching. The teachers can not only prepare listening material by themselves but also teaching based on the material provided by internet. Teaching in multimedia language laboratory enables easy operation for teachers and the teachers can understand the learning progress and process of students easily. The teacher can group the students based on their levels, provide different language sources to students of different degrees with multi-channel playback device and relieve the teacher of listening class from tedious and repetitive mechanical teaching.

The principle of communication presents the modern foreign language teaching idea which takes improving the language using ability and communication ability for students as objectives. Foreign language communication ability refers to the ability of learners who make use of the learned language knowledge to make language understanding (listening and reading) and language expression (speaking and writing). Based on this point, the computer multimedia courseware not only needs to meet the learning of language knowledge (grammar and vocabulary etc), but also provide conditions for practice of foreign language communication. Therefore, a better method is to combine the two together, that is place grammar, vocabulary and other language knowledge into simulated or real communication scenes, express language material with illustrations, voice and images, make full use of the interactive characteristics of multimedia, help learners to use while studying, learn language knowledge subconsciously and improve communication ability.

Before and after implementation, it made four types of different listening examinations to students, in which two listening examinations are with traditional listening questions and are selected from 5 the latest college English test 46 at random, which is composed of five parts: statement dictation, statement comprehension, Conversation comprehension, passage comprehension and spot dictation. It is well known that the answers of these questions are very objective and the students choose a correct answer from the given A, B, C, D options according to the recording, while for dictation part, the students are requested to write down the same words or sentences as recorder. Each part has ten questions and each question with two points, the total points are 100. The test needs to be finished in half an hour. In addition, the content of another two tests are from the fragments of 5 Family Album USA 6, which requests the students to answer the questions according to video clip and most of answers are understandable and open.

\section{References}

1. S. Li, "Multimedia computer assisted instruction in college English teaching," Proceedings-4th International Conference on Computational and Information Sciences, ICCIS 2012, pp. 754-757.

2. B. Shi, "Empirical research on feasibility and effect of computer-aided College English teaching model," Proceedings-2009 International Conference on Information Engineering and Computer Science, ICIECS 2009, pp. 236-241. https://doi.org/10.1109/iciecs. 2009.5362868

3. Y. Wang, Y. Bao, "Research on human-computer interaction of English teaching at local area network," ICCASM 2010 - 2010 International Conference on Computer Application 
Paper-Design and Research on English Listening Teaching Assisted by Computer Multimedia

and System Modeling, ICCASM 2010, Vol. 7, pp. 2718-2722. https://doi.org/10.1109/icc asm.2010.5620224

4. Q.H. Yang, "Research of college English teaching based on computer network technology, Lecture Notes in Electrical Engineering, Vol. 206, pp. 375-382, April 2013. https://doi.org/10.1007/978-1-4471-4790-9 48

5. X. Wu, H. Chen, "Computer-based educational game and its application in college English teaching in China," 2011 International Conference on Multimedia Technology, ICMT 2011, pp. 3008-3011.

6. X.H. Chen, "The research on English autonomous learning monitoring theory and application in the network environment," Applied Mechanics and Materials, vol.12, pp.60796082, March 2014. https://doi.org/10.4028/www.scientific.net/AMM.644-650.6079

7. J. Song, "The English teaching model of cooperative learning in the network environment in higher vocational education," Communications in Computer and Information Science, vol. 218, pp. 100-104, August 2012. https://doi.org/10.1007/978-3-642-23357-9 19

8. Q.L. Sun, "Information under the network environment using computer information security technology," Proceedings-2015 International Conference on Intelligent Transportation, ICITBS 2015, pp. 474-477.

9. M.Q. Xu, "The research on out-of-class autonomous English learning in computer-and network-assisted environment," Advances in Intelligent and Soft Computing, vol. 36, pp. 453-459. August 2011. https://doi.org/10.1007/978-3-642-24775-0 71

10. D.L. Yang, H. Zheng, "Research on the framework of new college English teaching mode integrating cooperative and autonomous learning in the network multimedia environment," ICETC 2010-2010 2nd International Conference on Education Technology and Computer, vol. 3, pp. 3256-3259, April 2010

11. X.H. Chen, "The research on English autonomous learning monitoring theory and application in the network environment". Applied Mechanics and Materials, Vol.12, pp.60796082, 2014. https://doi.org/10.4028/www.scientific.net/AMM.644-650.6079

12. S.F. Han, S. Miao, "On college English teaching of writing in the network environment". 2011 International Conference on Multimedia Technology, ICMT 2011, pp.588-590. https://doi.org/10.1109/ICMT.2011.6002176

13. S. Li, "Survey research on college students' English learning anxiety in the computer network environment". ICCSE 2011-6th International Conference on Computer Science and Education, Vol.36, pp.1010-1012, 2011.

14. D.L. Yang, Zheng, H., "Research on the framework of new college English teaching mode integrating cooperative and autonomous learning in the network multimedia environment". ICETC 2010-2010 2nd International Conference on Education Technology and Computer, Vol.3, pp. 3256-3259, 2010.

15. J. Zhou, Chen, X.H., "Analysis and simulation of computer virus propagation models in the network environment". Advanced Materials Research, Vol. 204, pp.433-436, 2014.

16. Y. Wang, "Research on human-computer interaction of English teaching at local area network". ICCASM 2010 - 2010 International Conference on Computer Application and System Modeling, Vol. 2, pp. 2718-2722, May 2010.

17. Z. Lei, X. Wei, "The analysis of English network computer aid test system model and technology selection". 2011 International Conference on Internet Technology and Applications, vol.35, pp.236-248, 2011. https://doi.org/10.1109/itap.2011.6006325

18. X.M. Wang, Y.J. Yang, and X. Wen, "Research and design of computer-aided English textbook evaluation system". Proceedings of the 1st International Workshop on Education Technology and Computer Science, vol.3, pp.913-917, 2009. https://doi.org/10.1109/ etcs.2009.741 
19. M. Rahkila, M. Karjalainen, "Evaluation of learning in computer based education using log systems". Proceedings-Frontiers in Education Conference, vol. 1, pp.12-16, 1999. https://doi.org/10.1109/fie.1999.839266

20. H. Yamamoto, A. Ohtani, T. Kado, "Development and evaluation of computer-mediated education systems for customer engineers". IFIP Transactions A: Computer Science and Technology, vol.35, pp.205-214, 1993.

21. Y. Bai, "Comprehensive evaluation of education mode of university English model and swat analysis". Computer Modelling and New Technologies, vol.18, pp.1085-1088, 2014.

22. J. Jia, W.C. Chen, "The further development of CSIEC project driven by application and evaluation in English education". British Journal of Educational Technology, vol.40, pp.901-918, 2009. https://doi.org/10.1111/j.1467-8535.2008.00881.x

\section{Author}

Danlie Ni is with the College of Language, Chongqing University of Technology, Chongqing 400054, China (danlie_ni@yahoo.com).

Submitted 17 July 2016. Published as resubmitted by the author 03 October 2016. 